\title{
Organizational Justice Perceptions and Views on Violence of Branch Teachers Working in Primary Schools ${ }^{1}$
}

\author{
Mehmet Koç ${ }^{1}$, Cengiz Akçay ${ }^{2}$, Bertan $\mathrm{Akyol}^{3}$ \\ ${ }^{1}$ Ministry of National Education, Turkey \\ ${ }^{2}$ Prof. Dr., Aydın University, Faculty of Education, Department of Educational Sciences, Istanbul, Turkey \\ ${ }^{3}$ Assist. Prof. Dr., Adnan Menderes University, Faculty of Education, Department of Educational Sciences, Aydın, \\ Turkey \\ Correspondence: Bertan Akyol, Adnan Menderes University, Faculty of Education, Department of Educational Sciences, \\ Aydın, Turkey.
}

Received: July 21, 2016 Accepted: July 28, $2016 \quad$ Online Published: August 19, 2016

doi:10.11114/jets.v4i10.1756 URL: http://dx.doi.org/10.11114/jets.v4i10.1756

\begin{abstract}
The aim of this research is to determine the organizational justice perceptions and perspectives toward violence of branch teachers in primary school. In this frame, the correlation between dimensions of organizational justice perceptions and perspectives toward violence of teachers was examined and all dimensions of this relation if differentiating or not according to various demographic, occupational and the school's property variables were examined. In this study, the literature survey was made and "Likert-type" two scales that were previously developed has been applied all schools within the Gaziantep Province. The data that was obtained through 'Organizational Justice Scale' and 'Inventory for Sources of Violence at Schools According to Teachers' from 617 middle school branch teacher was analyzed by using SPSS 20.0 program. Percentage, arithmetic mean and standard deviation statistics were used in descriptive statistics analysis. For Further analysis in parametric tests, t-test, Chi-square, nonparametric in more than two groups in one-way ANOVA, Kruskal Wallis non-parametric test is used H-statistics. At the end of analysis of the data; was stated that negatively and low levels relationship was seen between organizational justice dimensions and the perception of the school violence. As the conclusion of the study it can be stated that the teachers' perceptions of justice may arise together with the cause of violence.
\end{abstract}

Keywords: organizational justice, violence, violence in school

\section{Introduction}

Humankind has become the most important production factor of knowledge today. Humans, who produce, transfer and develop knowledge, have become the focal point of production processes. Organizations need to obtain qualified manpower and use this power in the most efficient way to succeed in the rapidly changing and competitive environment and conditions. The best way to make use of the knowledge that human beings increased and carried from past to present is providing them with working environments and fields where they can perform best. All feedback teachers receive in their working environments at schools shape their thinking, attitudes and psychology. Teachers' performances are affected accordingly. Additionally, according to teachers, the sources and reasons of violence students are exposed to at schools make the most basic issue of education.

Turkish Language Institution provides for different definitions for the concept of justice. Justice is the "enabling the use of rights obtained by laws for everyone". Justice is "the public institutions and organizations that perform this task". Justice refers to "suitability with rights and law, looking after rights". Justice is "providing everyone with what they deserve through their rights, righteousness" (TDK, 2013). Additionally, in terms of content, justice is merely handing someone their rights. In this context, individuals or people groups have certain rights. The most obvious rights are services, interests or money. However, rights are not limited to these. Social phenomena, such as respect, loyalty and

\footnotetext{
${ }^{1}$ Some of the data given in this study was orally presented in 8th National Congress on Educational Administration between 7-9 of November, 2013.
} 
dignity are among these rights. Justice has been used to secure individuals' rights, thoughts and interests, preserve human dignity, and provide human liberties (Açıkgöz, 2009, p. 46). On the other hand, organization justice explains the role of justice within an organization, and is a concept that is important in terms of the functioning of the organization and the satisfaction of its employees (Greenberg, 1987). Organizational justice is a concept that is related to how the acquisitions are shared and how these are perceived by the employees (Ambrose, 2002).

The concept of organizational justice covers individual measurements of employees' their own outputs, the sharing of justice within the organization, and following correct processes while decision makers share the outputs (Çınar, 2002). As it is stated by Akyol and Akçay (2013), from a broader perspective, organization justice suggests how the rewards and punishment should be shared and how the procedures should be used during sharing decisions. Consequently, organizational justice is an issue that is becoming more important in work life, and includes the domination and promotion of moral practices and procedures within the organization. Researchers, who have studied the concept of organization justice, and have developed theories on the subject field (Adams, 1965; Homans, 1961; Leventhal, 1980), claim in their studies that organizational justice is an important element in providing organizational efficiency and employee satisfaction (Greenberg, 1990).

Organizational justice refers to the individuals' perceptions of justice about the practices in their organizations. The members of an organization compare themselves with other members of their organization. They expect that rules are applied to everyone equally, have equal rights in time offs, equal work are paid equally, benefit from some social facilities equally with others, and awards or promotions are distributed equally. However, perception of justice is not only centred on outputs and the comparison of outputs. The rules of the organization, the way these rules are applied, and the interactions between individuals are also in the centre of the perception of justice (Özdevecioğlu, 2003, p. 77-96).

According to the related literature, organizational justice has three dimensions. The first of these is "Distributive Justice": Distributive justice refers to employees' perceptions related to whether the acquisitions and rewards are shared fairly. In other words, distributive justice is the perceptions of whether the acquisitions of employees are evaluated correctly and realistically based on the performance. According to another definition, distributive justice is the perception of justice formed with the comparison of the real value and the deserved value of what an organization or individual produces (Polat, 2007, p. 12). Another dimension of organizational justice is 'Procedural Justice': Procedural justice refers to the justice perceived while the outputs, distributed in the organization, such as salary or promotion, are defined. Employees are not passive beings, they can observe and evaluate how the organization runs. They are not only interested in the job done, but also how that job is done (Selekler, 2007, p. 20). The last dimension of organizational justice is "Interactional Justice". According to the most general definition, interactional justice refers to managers' explaining the decision making process related to the distributions to the employees of the organization in a respectful and honest way. According to Greenberg, perceptions of the process justice are also affected from factors other than the formal processes used in the distribution of the acquisitions. This factor is interactional justice, which refers to the explanations of the decision maker to the one affected from the decision about the attitudes and the decisions. Interactional justice covers behaviours like informing the employees about the decisions, which is defined as valuing, and respecting employees, and as a social value (İçerli, 2010, p. 87).

The concept of violence, which is studied along with the perception of organizational justice in the present research, and defined as toughness, strictness, using brute force instead of chastening verbally, and going overboard with reprimand and punishment, is a kind of behaviour that is related with aggression. However, violence and aggression are not the synonymous. Violence refers to backbreaking or provoking acts towards any individual, being or meta, or sometimes abstaining act or inertia. In other words, any kind of physical attack is included in the definition of violence, while some non-physical and verbal behaviours are also included in this concept (Ünsal, 1996, p. 29).

According to Turkish Language Society, violence is the use of brute force on the dissenters instead of reconciliation, and extremism in feelings and behaviours (TDK, 2013). Besides its general definition, perception of violence and violent behaviours that is felt in business life today is both the most important agenda of school organizations and the research subject of school security studies. The concept of violence at schools refers to aggressive and crime-like behaviours that produce negative consequences in the school environment, damage learning processes of students, and prevent their development. In general terms, violence at schools covers threats and physical attacks occurring between students and students; students and teachers or school managers and school staff (MEB, 2008, p. 12).

Violence refers to the occurrence of undesired behaviours that do not fit with the objectives and expectations of schools in an excess manner. It is endangering the psychological and physical security of especially the children (Memduhoğlu and Taşdan, 2007). As is the case throughout the world, violence has become widespread in Turkey as well, become a social problem that involves school age children and young people, and violence incidents at schools have become 
attention-grabbing (Karataş, 2011). According to Mahiroğlu and Buluç (2003), violence acts, which once considered as a part of education as a tool of disciplining or punishing students, today have become an issue of debate among educators, lawyers and other groups. The following conclusions were reached at through these debates:

- Violence results in the occurrence of criminal and aggressive behaviours among students and children.

- It is a cause of depression.

- It causes psychological problems among students and children.

- Different punishment practices are more effective than violence in keeping individuals away from faulty behaviours.

- Individuals, who are punished through violence, are prone to repeat similar criminal or faulty acts.

- Individuals, who are exposed to violence, isolate themselves from the society.

In the broadest sense, violence refers a way of behaving related to aggression. They are acts intended at individuals, that are not wanted by the individual, provoke and wear out the individual (Tutar, 2004). Violence is also a problematic field for teachers besides students. Previous studies on the violence at schools have reported that teachers serving at secondary level of education are more at risk than the teachers who serve at primary level, and some violent acts may even end up in the death of teachers. These unpleasant incidents have negative effects on the motivations of teachers, and in some cases some teachers may leave their professions (Memduhoğlu and Taşdan, 2007). Accordingly, the subject point of the present research is seeking the answer to the question "do the perceptions of violence change at a significant level when the organizational justice perceptions change?" among teachers who serve at schools which carry the most special task in raising individuals. Accordingly, the purpose of the present research is studying the relations between teachers' organizational justice perceptions and violence perceptions and in this context, presenting the relations between dimensions of organizational justice; distributive justice, procedural justice and interactional justice and the perceptions of violence; and additionally finding out whether these dimension vary by some demographic features, professional features and features of schools.

In accordance with the purpose of the present research; the answers to the following sub-problems are sought;

1. What are teachers' perceptions of justice?

2. Do teachers' perceptions of justice vary by demographic features (gender, age), professional features (length of service in the profession, school type, length of service at the present school), and the features of the school they serve at (school population, class population)?

3. What are teachers' perceptions of the reasons of violence?

4. Is there any significant relationship between the dimensions that form teachers' perceptions of justice and their perceptions of reasons of violence?

\section{Method}

The present research was made in comparative survey model (Karasar, 2013) as the purpose is studying justice perceptions and perceptions of the reasons of violence among a group of teachers, and defining the relationships between these.

\subsection{Participants}

The universe of the research consists of 1900 branch teachers who taught 5-8th graders in 114 primary school in Sehitkamil district of Gaziantep in 2012-2013 academic year. Through simple random sampling method, data collection tool was sent to 1100 teachers. 617 of them voluntarily participated in the survey. However, 561 of the scales filled by the participants were taken into consideration because of misfiled scales. As the demographic features of the participants are analyzed, it can be seen that 278 of the participants are felame and 283 of them are male. The ages of participants vary from 20 to 60 . Additionally, occupational length of service of the teachers range from 1 to 30 years. Teachers who are the participants of the study work in the same school from 1 to 14 years.

\subsection{Instruments}

Justice perceptions of teachers were defined with "Organizational Justice Scale". Organizational Justice Scale was developed in order to define primary school branch teachers' organizational justice perceptions by Niehoff and Moorman (1993), translated to Turkish by Wasti (2001), who also tested the validity and reliability of the scale, and adapted to Turkish by Gürpınar (2006).

Original form of organizational justice scale consists of 20 items and 3 dimensions. These dimensions are distributive justice, procedural justice and interactional justice. Moorman reported that Cronbach Alpha internal consistency for all three dimensions were over .90 (Niehoff and Moorman, 1993). Cronbach alpha internal consistency coefficient of the 
Turkish form of the scale, which was adapted by Gürpınar (2006), was found as .96 (Laçinoğlu, 2010: 54). Internal consistency coefficients for the dimensions were calculated as .82 for distributive justice, .93 for procedural justice and .97 for interactional justice.

"Inventory for Sources of Violence at Schools According to Teachers" developed by Parladir (2009) was employed in order to define teachers' perspectives related to the reasons of violence. The first part of the inventory consists of a scale that was developed in order to define primary school teachers' perceptions related to the sources of violence. This part consists of 7 dimensions and 45 items on the sources of violence. The scale on the reasons of violence was employed not on dimensions basis but as a whole. Accordingly, Cronbach Alpha coefficient of internal reliability for 45 -item scale was found as .94 .

\subsection{Data Analysis}

Data collected for the present research were analysed on SPSS 20 (Statistical Package Program for Social Sciences). Considering the sub-problems and the characteristics of the collected data, the following techniques were adopted for data analysis. Frequencies, percentages, averages, parametric difference tests and correlation analysis tests were used in analysis. Descriptive analyses, such as percentages and frequencies were calculated for the data collected with the personal information form used in the present research, and obtained findings were tabulated and presented in findings part. The differences between categorical variables with two independent groups were analysed with independent samples t-test. The differences between continuous variables with more than two independent groups were tested with one-way variance analysis (ANOVA). Linear correlations between two continuous variables were tested with Pearson Correlation coefficient.

\section{Results}

First results on the teachers' perceptions of the dimensions of organizational justice are presented in this part. Tables including teachers' perceptions of the distributive, procedural and interactional justice dimensions are presented below.

Table 1. Teachers' Perceptions of "Distributive Justice" Dimension

\begin{tabular}{|c|c|c|c|c|c|c|c|c|c|c|c|c|}
\hline \multirow{3}{*}{$\begin{array}{l}\text { Items } \\
\text { (Distributive Justice) }\end{array}$} & \multicolumn{2}{|c|}{ Strongly disagree } & \multicolumn{2}{|c|}{ Disagree } & \multicolumn{2}{|c|}{ Indecisive } & \multicolumn{2}{|c|}{ Agree } & \multicolumn{2}{|c|}{ Strongly agree } & \multirow{2}{*}{$\begin{array}{l}\text { Art. Ave. } \\
(x)\end{array}$} & \multirow{3}{*}{$\begin{array}{l}\text { St. Dev. } \\
\mathrm{Sd} \\
4,3\end{array}$} \\
\hline & S & $\%$ & S & $\%$ & $\mathrm{~S}$ & $\%$ & $\mathrm{~S}$ & $\%$ & $\mathrm{~S}$ & $\%$ & & \\
\hline & 100 & 17,8 & 124 & 22,1 & 193 & 34,5 & 104 & 18,6 & 40 & 7,1 & 14,4 & \\
\hline My work schedule is fair. & 62 & 11,1 & 102 & 18,2 & 222 & 39,6 & 132 & 23,5 & 43 & 7,7 & 3,4 & 1,1 \\
\hline I think that my level of pay is fair & 158 & 28,2 & 154 & 27,5 & 145 & 25,8 & 73 & 13,0 & 31 & 5,5 & 2,5 & 1,2 \\
\hline I consider my work load to be quite fair & 62 & 11,1 & 102 & 18,2 & 222 & 39,6 & 132 & 23,5 & 43 & 7,7 & 2,9 & 1,1 \\
\hline I think that the level of gaining is fair & 158 & 28,2 & 154 & 27,5 & 145 & 25,8 & 73 & 13,0 & 31 & 5,5 & 2,4 & 1,2 \\
\hline I feel that my job responsibilities are fair & 58 & 10,3 & 106 & 18,9 & 233 & 41,5 & 112 & 20,0 & 52 & 9,3 & 2,9 & 1,1 \\
\hline
\end{tabular}

As presented in Table 1, arithmetic average of teachers' scores on their perceptions of the distributive justice dimension is not very high $(14,4 / 5=2,9)$. In terms of items, almost one third of teachers' perceptions on "My work schedule is fair" $(31.2 \%)$ and "I consider my work load to be quite fair" (31.2\%) items are positive. On the other hand, more than half of the teachers' perceptions on "I think that the level of gaining is fair" (55.7\%) and "I think that my level of pay is fair" $(55.7 \%)$ are negative. Accordingly, the findings presented in this table indicate that the participants aren't happy with the awards and wage they get.

Table 2. Teachers' Perceptions of the "Procedural Justice" Dimension

\begin{tabular}{|c|c|c|c|c|c|c|c|c|c|c|c|c|}
\hline \multirow[t]{3}{*}{$\begin{array}{l}\text { Items } \\
\text { (Procedural Justice) }\end{array}$} & \multicolumn{2}{|c|}{$\begin{array}{l}\text { Strongly } \\
\text { disagree }\end{array}$} & \multicolumn{2}{|c|}{ Disagree } & \multicolumn{2}{|c|}{ Indecisive } & \multicolumn{2}{|c|}{ Agree } & \multicolumn{2}{|c|}{$\begin{array}{l}\text { Strongly } \\
\text { agree }\end{array}$} & \multirow{2}{*}{$\begin{array}{l}\text { Art. } \\
\text { Ave. } \\
(x)\end{array}$} & \multirow{2}{*}{$\begin{array}{l}\text { St. } \\
\text { Dev. } \\
\text { SD }\end{array}$} \\
\hline & $\mathrm{S}$ & $\%$ & $\mathrm{~S}$ & $\%$ & $S$ & $\%$ & $\mathrm{~S}$ & $\%$ & $\mathrm{~S}$ & $\%$ & & \\
\hline & 24 & 4,3 & 68 & 12,1 & 184 & 32,8 & 200 & 35,6 & 86 & 15,3 & 20,7 & 5,3 \\
\hline $\begin{array}{l}\text { Job decisions made by my manager are in } \\
\text { an unbiased manner }\end{array}$ & 21 & 3,7 & 51 & 9,1 & 165 & 29,4 & 229 & 40,8 & 95 & 16,9 & 3,6 & 1,0 \\
\hline $\begin{array}{l}\text { My manager makes sure that all employee } \\
\text { concerns are heard before decisions are } \\
\text { made }\end{array}$ & 21 & 3,7 & 85 & 15,2 & 184 & 32,8 & 186 & 33,2 & 85 & 15,2 & 3,4 & 1,0 \\
\hline $\begin{array}{l}\text { To make job decisions, my manager collects } \\
\text { accurate and complete information }\end{array}$ & 22 & 3,9 & 71 & 12,7 & 200 & 35,7 & 187 & 33,3 & 81 & 14,4 & 3,4 & 1,0 \\
\hline $\begin{array}{l}\text { My manager clarifies decisions and provides } \\
\text { additional information when requested by } \\
\text { employees }\end{array}$ & 21 & 3,7 & 54 & 9,6 & 190 & 33,9 & 209 & 37,3 & 87 & 15,5 & 3,5 & 1,0 \\
\hline $\begin{array}{l}\text { All job decisions are applied consistently } \\
\text { across all affected employees. }\end{array}$ & 26 & 4,6 & 73 & 13,0 & 198 & 35,3 & 183 & 32,6 & 81 & 14,4 & 3,4 & 1,1 \\
\hline $\begin{array}{l}\text { Employees are allowed to challenge or } \\
\text { appeal job decisions made by the manager }\end{array}$ & 35 & 6,2 & 71 & 12,7 & 166 & 29,6 & 204 & 36,4 & 85 & 15,2 & 3,4 & 1,1 \\
\hline
\end{tabular}


As presented in Table 2, teachers' average scores for their perceptions on the procedural justice dimension is pretty high $(20,7 / 6=3,45)$. The study of the findings presented in Table 2 on items basis also shows that teachers' perceptions on all items are positive. These findings indicate that school managers attach importance to procedural justice as they make decisions related to management.

Table 3. Teachers' Perceptions of the "Interactional Justice” Dimension

\begin{tabular}{|c|c|c|c|c|c|c|c|c|c|c|c|c|}
\hline \multirow[t]{3}{*}{$\begin{array}{l}\text { Items } \\
\text { (Interactional Justice) }\end{array}$} & \multicolumn{2}{|c|}{$\begin{array}{l}\text { Strongly } \\
\text { disagree }\end{array}$} & \multicolumn{2}{|c|}{ Disagree } & \multicolumn{2}{|c|}{ Indecisive } & \multicolumn{2}{|c|}{ Agree } & \multicolumn{2}{|c|}{$\begin{array}{l}\text { Strongly } \\
\text { agree }\end{array}$} & \multirow{2}{*}{$\begin{array}{l}\text { Art. } \\
\text { Ave. } \\
(x)\end{array}$} & \multirow{2}{*}{$\begin{array}{l}\text { St. } \\
\text { Dev. } \\
\text { SD }\end{array}$} \\
\hline & $\mathrm{S}$ & $\%$ & $S$ & $\%$ & $\mathrm{~S}$ & $\%$ & $\mathrm{~S}$ & $\%$ & $\mathrm{~S}$ & $\%$ & & \\
\hline & 14 & 2,6 & 50 & 8,9 & 155 & 27,6 & 224 & 40,0 & 118 & 21,0 & 33,1 & 7,8 \\
\hline $\begin{array}{l}\text { When decisions are made about my job, my } \\
\text { manager treats me with kindness and } \\
\text { consideration }\end{array}$ & 12 & 2,1 & 43 & 7,7 & 140 & 25,0 & 245 & 43,7 & 121 & 21,6 & 3,8 & ,9 \\
\hline $\begin{array}{l}\text { When decisions are made about my job, my } \\
\text { manager treats me with respect and dignity }\end{array}$ & 8 & 1,4 & 41 & 7,3 & 145 & 25,8 & 236 & 42,1 & 131 & 23,4 & 3,8 & ,9 \\
\hline $\begin{array}{l}\text { When decisions are made about my job, my } \\
\text { manager is sensitive to my personal needs. }\end{array}$ & 18 & 3,2 & 60 & 10,7 & 153 & 27,3 & 226 & 40,3 & 104 & 18,5 & 3,7 & 1,0 \\
\hline $\begin{array}{l}\text { When decisions are made about my job, my } \\
\text { manager deals with me in a truthful manner. }\end{array}$ & 15 & 2,7 & 41 & 7,3 & 160 & 28,5 & 224 & 39,9 & 121 & 21,6 & 3,7 & ,9 \\
\hline $\begin{array}{l}\text { When decisions are made about my job, my } \\
\text { manager shows concerns for my rights as } \\
\text { an employee }\end{array}$ & 15 & 2,7 & 43 & 7,7 & 161 & 28,7 & 223 & 39,8 & 119 & 21,2 & 3,7 & ,9 \\
\hline $\begin{array}{l}\text { My manager discusses with me the } \\
\text { implications of the decisions concerning my } \\
\text { job }\end{array}$ & 15 & 2,7 & 46 & 8,2 & 158 & 28,2 & 223 & 39,8 & 119 & 21,2 & 3,7 & ,9 \\
\hline $\begin{array}{l}\text { My manager offers adequate justifications } \\
\text { for decisions made about my job. }\end{array}$ & 15 & 2,7 & 54 & 9,6 & 152 & 27,1 & 227 & 40,5 & 113 & 20,1 & 3,7 & ,9 \\
\hline $\begin{array}{l}\text { When decisions are made about my job, my } \\
\text { manager offers explanations that make } \\
\text { sense to me. }\end{array}$ & 18 & 3,2 & 63 & 11,2 & 168 & 29,9 & 201 & 35,8 & 111 & 19,8 & 3,6 & 1,0 \\
\hline $\begin{array}{l}\text { My manager explains very clearly any } \\
\text { decision made about my job. }\end{array}$ & 14 & 2,5 & 57 & 10,2 & 156 & 27,8 & 215 & 38,3 & 119 & 21,2 & 3,7 & 1,0 \\
\hline
\end{tabular}

As presented in Table 3, teachers' average scores for their perceptions on the interactional justice dimension is pretty high $(33,1 / 9=3,68)$. The study of the findings presented in Table 3 on items basis also shows that teachers' perceptions on almost all items are positive. Accordingly, school managers attach importance to interactional justice as they make decisions related to management.

After the investigation of teachers' perceptions on the dimensions of organizational justice, the findings related to whether teachers' perceptions on the organizational justice vary by demographic variables are presented here.

Table 4. T-Test Analysis Results on the Variation in Teachers' Organizational Justice Perceptions by Gender

\begin{tabular}{llllllll}
\hline Dimensions & Gender & $\mathrm{N}$ & $(\bar{x})$ & $\mathrm{S}$ & $\mathrm{sd}$ & $\mathrm{t}$ & $\mathrm{p}$ \\
\hline Distributive & Female & 278 & 14,0 & 4,2 & 559 & $-2,3$ &, 02 \\
& Male & 283 & 14,8 & 4,3 & & & \multirow{2}{*}{01} \\
Procedural & Female & 278 & 20,1 & 5,4 & 559 & & \multirow{2}{*}{, 001} \\
& Male & 283 & 21,4 & 5,2 & & & $-3,2$ \\
& Female & 278 & 32,1 & 7,8 & 559 & & \\
& Male & 283 & 34,1 & 7,8 & & & \\
\hline
\end{tabular}

As presented in Table 4, there are significant differences between the perceptions of male and female teachers in terms of distributive $[\mathrm{t}(559)=2,28, \mathrm{p}<, 02]$, procedural $[\mathrm{t}(559)=2,8, \mathrm{p}<, 01]$ and interactional $[\mathrm{t}(559)=3,2, \mathrm{p}<, 02]$ justice dimensions. Male teachers' $(=14,8)$ perceptions of distributive justice are more positive than female teachers $(=14)$. Similarly, male teachers $(=21,4)$ have more positive perceptions of procedural justice than female teachers $(=20,1)$. The results are the same for the interactional justice dimension. Accordingly, male teachers' perceptions $(=34,1)$ are higher than female teachers $(=32,1)$. Consequently, male teachers' perceptions of organizational justice are more positive than female teachers. The questionnaire form employed in the present research didn't question the genders of the managers of the participants. However, considering that most school managers in Turkey are male, male teachers may have developed more positive perceptions towards their managers of the same sex.

Variance analysis was conducted in order to find out whether teachers' perceptions of organizational justice varied by age. For this procedure, first homogeneity of the groups was tested with Levene test. According to the analyses, Levene test results were .686 for distributive justice dimension, 1.222 for procedural justice dimension, and 1.394 for interactional justice dimension. Accordingly, these groups don't differ from each other at a significant level. One-way ANOVA analysis results are presented in Table 5. 
Table 5. ANOVA Test Results on the Variation in Teachers' Perceptions of Organizational Justice by Age

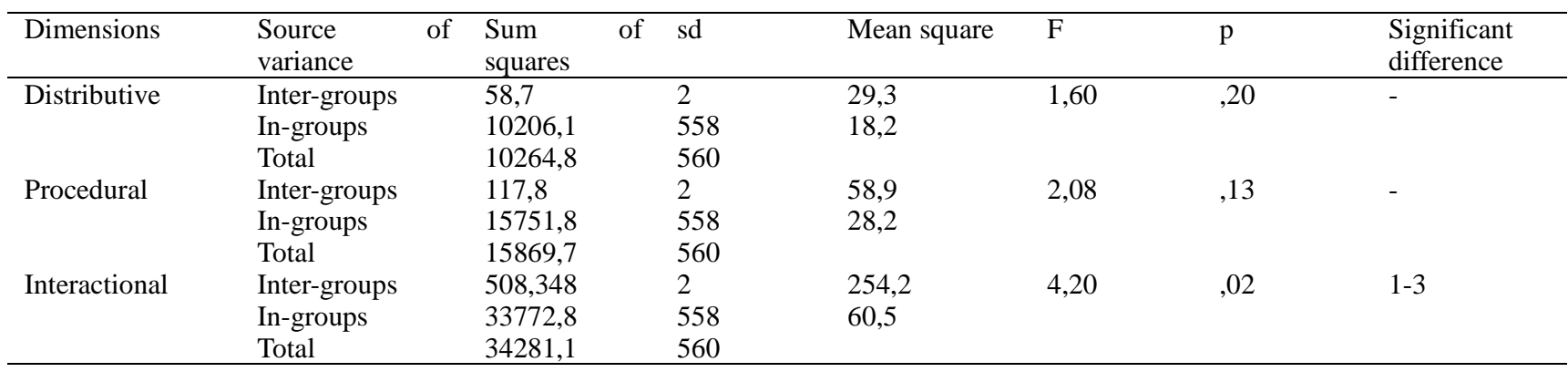

According to the analyses, teachers' perceptions of distributive justice $[\mathrm{F}(2,558)=1,60 \mathrm{p}>, 20]$ and procedural justice $[\mathrm{F}(2,558)=2,08 \mathrm{p}>, 13]$ don't vary significantly by age, while interactional justice perceptions $[\mathrm{F}(2,558)=1,60 \mathrm{p}<, 02]$ vary by age at a significant level. In order to find out the direction of variation Dunnet C statistic among post hoc tests, which enables inter-groups comparisons when inter-groups variances are not equal, was used (Büyüköztürk, 2007). Accordingly, interactional justice perceptions of teachers, who are 41 years old or older, are more positive than the teachers in 20-30 age group (Dunnet $\mathrm{C}=3,14$ ). It is believed that managers are more kind, respectful, and sincere to older teachers, which may have resulted in this finding.

The variation in teachers' perceptions of organizational justice by length of service was tested with one-way ANOVA test. For this procedure, first the homogeneity of the groups was tested with Levene test. Accordingly, Levene test results were found as .796 for distributive justice dimension, 1.295 for procedural justice dimension and 1.138 for the interactional justice dimension. Accordingly, there aren't significant differences between these groups, on the contrary they are similar. These findings are presented in Table 6.

Table 6. ANOVA Test Results on the Variation in Teachers' Perceptions of Organizational Justice by Length of Service

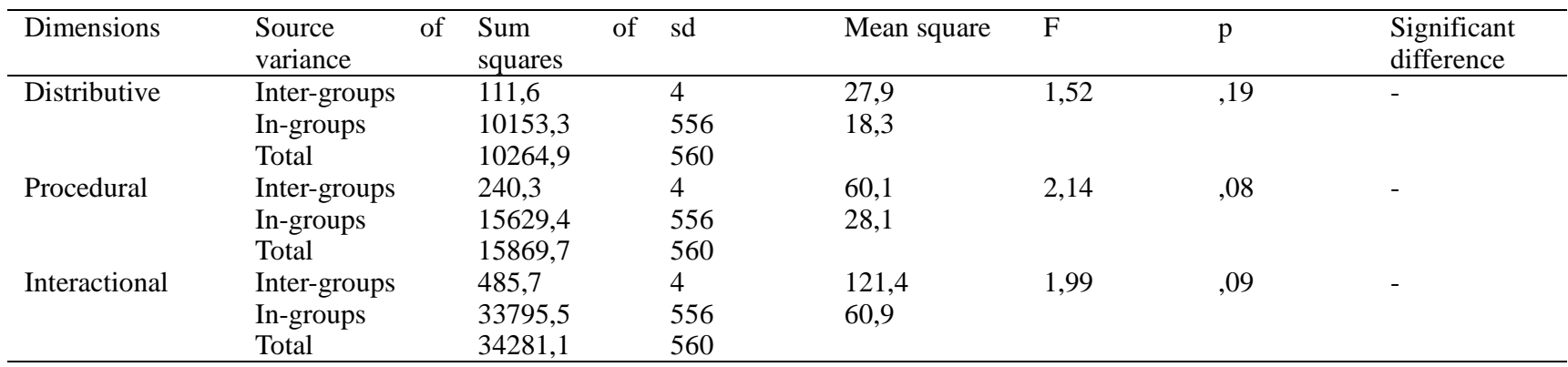

According to the analysis results, teachers' perceptions of distributive justice $[\mathrm{F}(4,556)=1,52 \mathrm{p}>, 19]$, procedural justice $[\mathrm{F}(2,556)=2,14 \mathrm{p}>, 08]$ and interactional justice $[\mathrm{F}(2,556)=1,99 \mathrm{p}<, 09]$ don't vary by length of service at a significant level. Accordingly, there aren't significant differences between teachers with different lengths of service in terms of their perceptions of organizational justice dimensions.

The variation in teachers' perceptions of organizational justice by length of service at their present school was tested with one-way ANOVA test. For this procedure, first the homogeneity of the groups was tested with Levene test. Accordingly, Levene test results were found as 2.260 for distributive justice dimension, 2.469 for procedural justice dimension and 1.932 for the interactional justice dimension. Accordingly, there aren't significant differences between these groups, on the contrary they are similar. These findings are presented in Table 7.

Table 7. ANOVA Test Results on the Variation in Teachers' Perceptions of Organizational Justice by Length of Service at the Present School

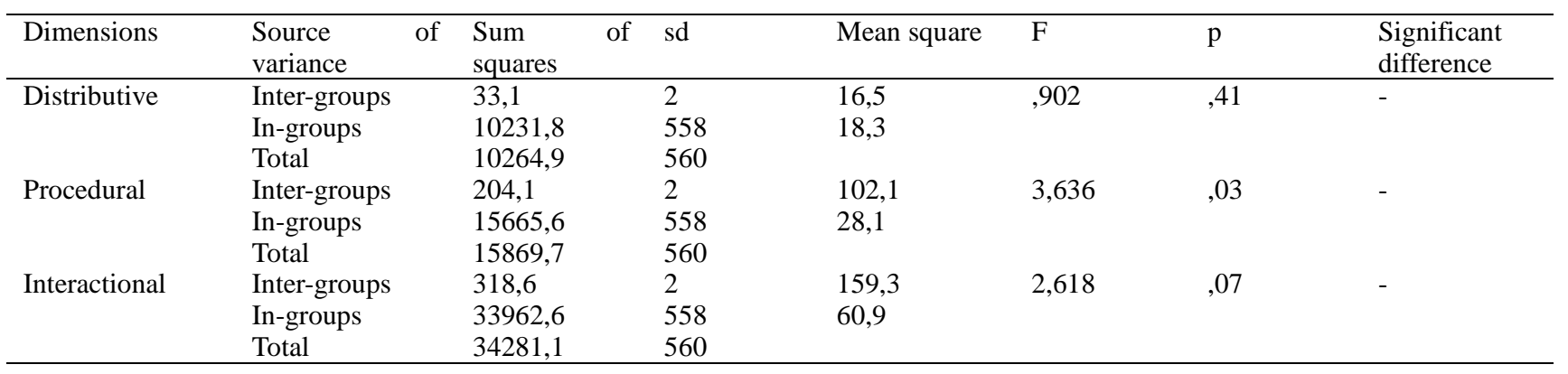


As presented in Table 7, teachers' perceptions of distributive justice $[F(2,558)=, 902 \mathrm{p}>, 41]$ and interactional justice $[\mathrm{F}(2,558)=2,618 \mathrm{p}>, 02]$ don't vary at a significant level by their length at their present school. On the other hand, their perceptions of procedural justice $[\mathrm{F}(2,558)=2,08 \mathrm{p}>, 13]$ vary at a significant level by length of service at the present school. In order to find out the direction of variation Dunnet $\mathrm{C}$ statistic among post hoc tests, which enables inter-groups comparisons when inter-groups variances are not equal, was used (Büyüköztürk, 2007). Accordingly, procedural justice perceptions of teachers, who have been serving for 7 years or longer at their present school, are more positive than the teachers, who have been serving for 1-3 years (Dunnet $\mathrm{C}=1,713$ ).

The present research also investigated whether teachers' perceptions of organizational justice varied at a significant level by school population, class population, and social-sportive activities conducted at schools. First of all, in order to test the variation in teachers' perceptions by school population, the homogeneity of the groups was tested with Levene test. According to the analyses, Levene test results were found as 1.407 for distributive justice dimension, 3.241 for procedural justice dimension and 2.015 for interactional justice dimension. These findings indicate that these groups are similar to each other. The findings are presented in Table 8.

Table 8. ANOVA Test Results on the Variation in Teachers' Perceptions of Organizational Justice by School Population

\begin{tabular}{|c|c|c|c|c|c|c|c|c|}
\hline Dimensions & $\begin{array}{l}\text { Source } \\
\text { variance }\end{array}$ & of & Sum of squares & sd & Mean square & $\mathrm{F}$ & $\mathrm{p}$ & $\begin{array}{l}\text { Significant } \\
\text { difference }\end{array}$ \\
\hline \multirow[t]{3}{*}{ Distributive } & Inter-groups & & 878,724 & 4 & 219,681 & \multirow[t]{3}{*}{13,013} & \multirow[t]{3}{*}{, 00} & $1-2,1-3,1-4,1-5$ \\
\hline & In-groups & & 9386,153 & 556 & 16,882 & & & $3-2$ \\
\hline & Total & & 10264,877 & 560 & & & & \\
\hline \multirow[t]{3}{*}{ Procedural } & Inter-groups & & 417,128 & 4 & 104,282 & \multirow[t]{3}{*}{3,752} & \multirow[t]{3}{*}{, 01} & \multirow[t]{3}{*}{$1-3$} \\
\hline & In-groups & & 15452,598 & 556 & 27,792 & & & \\
\hline & Total & & 15869,725 & 560 & & & & \\
\hline \multirow[t]{3}{*}{ Interactional } & Inter-groups & & 346,349 & 4 & 86,587 & \multirow[t]{3}{*}{1,419} & \multirow[t]{3}{*}{, 23} & \multirow[t]{3}{*}{-} \\
\hline & In-groups & & 33934,799 & 556 & 61,034 & & & \\
\hline & Total & & 34281,148 & 560 & & & & \\
\hline
\end{tabular}

In order to test the variation in teachers' perceptions of organizational justice by class population, first the homogeneity of the groups was tested with Levene test. Accordingly, Levene test results were 1.124 for distributive justice, 1.514 for procedural justice and 4.150 for interactional justice dimensions. Accordingly, these groups are similar. One-way ANOVA test results are presented in Table 9.

As presented in Table 8, teachers' perceptions of distributive justice $[\mathrm{F}(4,556)=13,013,902 \mathrm{p}<, 00]$ and procedural justice $[\mathrm{F}(4,556)=3,752 \mathrm{p}<, 01]$ vary at a significant level by school population. On the other hand, teachers' perceptions of interactional justice don't vary significantly by this variable $[F(4,556)=1,419 \mathrm{p}>, 23]$. The direction of the variation was tested with Dunnet C statistics (Büyüköztürk, 2007). Accordingly, teachers, whose schools have a population between 0-500 students, have more positive perceptions than teachers, whose schools have populations of 501-1000 (Dunnet C=3,924), 1001-1500 (Dunnet C=5,498), 1501-2000 (Dunnet $\mathrm{C}=5,015$ ) and 2001 and more (Dunnet $\mathrm{C}=5,389)$ respectively. Another difference in distributive justice dimension was found between teachers, whose schools have a population of 501-1000 students and teachers, whose schools have a population of 1001-1500 students, in favour of the teachers, whose schools have lower populations (Dunnet $\mathrm{C}=-1,574$ ). Another significant difference was detected in procedural justice dimension. According to Dunnet $\mathrm{C}$ test, perceptions of teachers, whose schools have a population of 0-500 students, have more positive perceptions than teachers, whose schools have a population of 1000-1500 students (Dunnet $\mathrm{C}=3,686$ ). Accordingly, teachers' perceptions get more negative, as the populations of their schools are higher.

Table 9. ANOVA Test Results on the Variation in Teachers' Perceptions of Organizational Justice by Class Population

\begin{tabular}{|c|c|c|c|c|c|c|c|}
\hline Dimensions & $\begin{array}{l}\text { Source of } \\
\text { variance }\end{array}$ & $\begin{array}{l}\text { Sum } \\
\text { squares }\end{array}$ & $\mathrm{sd}$ & Mean square & $\mathrm{F}$ & $\mathrm{p}$ & $\begin{array}{l}\text { Significant } \\
\text { difference }\end{array}$ \\
\hline \multirow[t]{3}{*}{ Distributive } & Inter-groups & 215,655 & 2 & 107,828 & 5,987 & ,003 & $1-2,1-3$ \\
\hline & In-groups & 10049,222 & 558 & 18,009 & & & \\
\hline & Total & 10264,877 & 560 & & & & \\
\hline \multirow[t]{3}{*}{ Procedural } & Inter-groups & 52,594 & 2 & 26,297 & ,928 & ,396 & - \\
\hline & In-groups & 15817,131 & 558 & 28,346 & & & \\
\hline & Total & 15869,725 & 560 & & & & \\
\hline \multirow[t]{3}{*}{ Interactional } & Inter-groups & 67,130 & 2 & 33,565 &, 547 & ,579 & - \\
\hline & In-groups & 34214,018 & 558 & 61,315 & & & \\
\hline & Total & 34281,148 & 560 & & & & \\
\hline
\end{tabular}

Following the findings on teachers' perceptions of organizational justice and its dimensions, teachers' remarks on the reasons for violence are presented with descriptive statistics, such as numbers, arithmetic average, and standard deviations. 
According to the analyses, teachers' perceptions of distributive justice vary by the class populations at their schools at a significant level $[\mathrm{F}(2,558)=5,987 \mathrm{p}<, 00]$. On the other hand, teachers' perceptions of procedural justice $[\mathrm{F}(2,558)$ $=, 928 \mathrm{p}>, 396]$ and interactional justice $[\mathrm{F}(2,558)=, 547 \mathrm{p}>, 579]$ don't vary by class population variable at a significant level. The direction of the difference was tested with Dunnet C statistics (Büyüköztürk, 2007). Accordingly, perceptions of teachers, whose classroom populations are between 0-30, are more positive than the teachers, whose classroom populations are between 31-40 (Dunnet $\mathrm{C}=1,091$ ) and 41 or more (Dunnet $\mathrm{C}=2,013$ ). With more students in their classes, teachers may feel like that the success is lower in their classes, and also their attainments; so they may believe that they should be paid more than the teachers, who teach less students in their classes.

Table 10. Teachers' Perceptions on the Reasons of Violence

\begin{tabular}{|c|c|c|c|c|}
\hline \multirow[b]{2}{*}{ No } & \multirow{2}{*}{ Items } & \multirow[t]{2}{*}{$\mathrm{n}$} & \multirow{2}{*}{$\frac{\text { Art. Ave. }}{(\bar{x})}$} & \multirow{2}{*}{$\begin{array}{l}\text { St. Dev. } \\
\text { SD }\end{array}$} \\
\hline & & & & \\
\hline 1 & Students' being exposed to violence in the family & 561 & 3,9 & 1,1 \\
\hline 2 & Students' having a troubled family life & 561 & 4,1 & 1,1 \\
\hline 3 & Indifferent parents & 561 & 4,0 & 1,0 \\
\hline 4 & Parents' being unconscious in child raising & 561 & 3,3 & 1,2 \\
\hline 5 & Separated parents & 561 & 2,5 & 1,0 \\
\hline 6 & Teachers' reflecting personal problems on school & 561 & 2,5 & 1,0 \\
\hline 7 & Teachers' impatience towards students & 561 & 2,4 & 1,1 \\
\hline 8 & Teachers' being unloving towards students & 561 & 2,4 & 1,0 \\
\hline 9 & Inadequate interest and understanding from teachers towards students & 561 & 2,4 & 0,9 \\
\hline 10 & Teachers' teaching lessons boringly & 561 & 2,3 & 0,9 \\
\hline 11 & Teachers' strict sense of discipline & 561 & 2,1 & 1,0 \\
\hline 12 & Professionally incompetent teachers & 561 & 2,5 & 1,0 \\
\hline 13 & Teachers' incompetency in communicating with adolescents & 561 & 3,0 & 1,2 \\
\hline 14 & Students' anxiety and despair for their futures & 561 & 3,2 & 1,1 \\
\hline 15 & Disputes among student groups & 561 & 3,5 & 1,0 \\
\hline 16 & Students' need to prove themselves due to their age & 561 & 2,8 & 1,0 \\
\hline 17 & Social and economic status differences between students & 561 & 3,1 & 1,0 \\
\hline 18 & Jealousy among students & 561 & 3,8 & 1,1 \\
\hline 19 & Students' lack of concrete objectives & 561 & 2,9 & 1,1 \\
\hline 20 & Examination anxiety among students & 561 & 3,3 & 1,0 \\
\hline 21 & Lack of activities suiting students' abilities & 561 & 3,4 & 1,1 \\
\hline 22 & Students' seeing what taught at school as unimportant and boring & 561 & 3,8 & 1,0 \\
\hline 23 & Bad circle of friends & 561 & 3,6 & 1,1 \\
\hline 24 & Behavioural and personality disorders among students & 561 & 3,1 & 1,0 \\
\hline 25 & Exclusivity of girl or boy friends & 561 & 3,7 & 1,1 \\
\hline 26 & Violence being preferred as the solution of problems & 561 & 3,8 & 1,1 \\
\hline 27 & Increase in the number of self-centred individuals in the society & 561 & 3,8 & 1,0 \\
\hline 28 & Cultural degeneration in the society & 561 & 3,9 & 1,0 \\
\hline 29 & Economic problems in the society & 561 & 3,9 & 1,0 \\
\hline 30 & Violence being widespread in the society & 561 & 3,5 & 1,2 \\
\hline 31 & Unregulated school environments & 561 & 2,8 & 1,1 \\
\hline 32 & Unregulated departments at schools & 561 & 3,3 & 1,1 \\
\hline 33 & Inadequate parent-teacher association & 561 & 2,9 & 1,2 \\
\hline 34 & Insecure school entrances & 561 & 2,8 & 1,3 \\
\hline 35 & Ramblers' around school environment involving in the schools & 561 & 2,8 & 1,2 \\
\hline 36 & Inadequate and unregulated school yards & 561 & 2,9 & 1,2 \\
\hline 37 & Inadequate discipline from school management & 561 & 2,7 & 1,0 \\
\hline 38 & Boring school environment & 561 & 3,0 & 1,2 \\
\hline 39 & Inadequate guidance and counselling services at schools & 561 & 3,1 & 1,2 \\
\hline 40 & Inadequate social, cultural and sportive activities at schools & 561 & 3,2 & 1,3 \\
\hline 41 & Crowded schools and classes & 561 & 3,0 & 1,1 \\
\hline 42 & Over work load & 561 & 2,9 & 1,2 \\
\hline 43 & Inadequacy of the comforting lessons (art, music, physical education) & 561 & 3,7 & 1,2 \\
\hline 44 & Dis-functioning of MNE discipline regulations & 561 & 3,6 & 1,2 \\
\hline 45 & Unregulated Internet use & 561 & 3,7 & 1,1 \\
\hline Total & & 561 & 3,2 & 25,5 \\
\hline
\end{tabular}

Table 10 presents the results of the analysis conducted to reveal teachers' remarks on the reasons of violence. Accordingly, the items that were within "most of the time" range (3.41-4.20) respectively are; students' having a troubled family life (4.1); indifferent parents (4.0); students' being exposed to violence in the family (3.9); cultural degeneration in the society (3.9); economic problems in the society (3.9); increase in the number of self-centred individuals in the society (3.8); violence being preferred as the solution of problems (3.8); students' seeing what taught at school as unimportant and boring (3.8); jealousy among students (3.8); inadequacy of the comforting lessons (art, 
music, physical education); unregulated Internet use (3.7); dis-functioning of MNE discipline regulations; exclusivity of girl or boy friends (3.7); bad circle of friends (3.6); violence being widespread in the society (3.5) and disputes among student groups (3.5). On the other hand, the items that were within rarely range (1.81-2.60) were separated parents (2.5); teachers' impatience towards students (2.5); professionally incompetent teachers (2.5); teachers' being unloving towards students (2.4); inadequate interest and understanding from teachers towards students (2.4); teachers' teaching lessons boringly (2.3) and teachers' strict sense of discipline (2.1). These findings indicate that according to teachers, the reasons of violence are mostly family related and teacher related reasons are less effective comparatively.

Finally, the findings on the correlations between teachers' perceptions of organizational justice and the reasons of violence are presented in Table 11.

Table 11. Correlation Analysis Results on Teachers' Perceptions of Distributive, Procedural and Interactional Justice Scores and Reasons of Violence Scores

\begin{tabular}{|c|c|c|c|c|c|}
\hline Scale/Justice Dimen & sions & Distributive Justice & $\begin{array}{l}\text { Procedural } \\
\text { Justice }\end{array}$ & $\begin{array}{l}\text { Interactional } \\
\text { Justice }\end{array}$ & $\begin{array}{l}\text { Reasons } \\
\text { violence }\end{array}$ \\
\hline \multirow{3}{*}{$\begin{array}{l}\text { Reasons of violence } \\
\text { scale }\end{array}$} & Pearson Correlation &,$- 266^{* *}$ &,$- 248^{* *}$ &,$- 192^{* *}$ & 1 \\
\hline & Sig. (2-tailed) & 000 & 000 &, 000 & \\
\hline & $\mathrm{N}$ & 561 & 561 & 561 & 561 \\
\hline
\end{tabular}

**Correlation is significant at 0.01 level (2-way).

According to the findings presented in Table 11, there is a weak and negative correlation between teachers' perceptions of organizational justice and reasons of violence ( $r 2$ (distributive justice $x$ violence)=-,266, $r 2$ (procedural justice $x$ violence) $=-, 248, \mathrm{r} 2$ (interactional justice $\mathrm{x}$ violence $)=,-192, \mathrm{p}<, 01)$. Accordingly, as teachers' perceptions of justice are higher, their perceptions on the reasons of violence are lower. However, the weakness of this correlation prevents strong statements on the finding. Yet, we can claim that teachers' positive perceptions on the dimensions of organizational justice affect their remarks on the reasons of violence positively.

\section{Conclusion, Discussion and Suggestions}

The present research was conducted in order to investigate teachers' perceptions of organizational justice and their remarks on violence. The numbers of female and male participants were almost equal. Most of the participants were young and middle aged teachers and accordingly their length of service is not much long. These young teachers with short length of service also have not been serving at their present school for long. The numbers of teachers in terms of the type of school they serve at, as secondary school (5-8 grades) and primary school (1-8 grades), are also almost the same. Most of the participants serve at high population schools, and the population in most of their classes is less than 40 students. In terms of the social and sportive activities, $11.35 \%$ of the participants stated that these activities were "very adequate", $54.78 \%$ stated that the activities at their schools were "medium level" and $33.87 \%$ stated the activities at their schools were inadequate. Most of the participating teachers believe the social and sportive activities at their schools are "medium level".

In terms of distributive justice dimension, participants think that the distributed acquisitions, rights and attitudes in terms of their performances were inadequate. The participants' negative perception may result in their decreasing their performance and the effort they pay in their jobs. We can claim that participants believe the procedures are conducted fairly at their schools, in terms of procedural justice dimension. Additionally, the teachers in the work group believe their managers at their schools are respectful, honest and fair towards them.

Additionally, male teachers have more positive perceptions than female teachers in terms of distributive, procedural and interactional justice dimensions. In terms of distributive and procedural justice dimensions, all teachers of all age groups have similar perceptions. On the other hand, teachers who are " 41 years old and older" have more positive perceptions than teachers who are in "20-30" age group. Teachers' perceptions of organizational justice also don't vary by the length of service at their present school.

In terms of school population, there are significant differences in teachers' perceptions of distributive justice between teachers, whose schools have a population of "0-500" and the ones with "1001-1500" and "501-1000" population. In terms of procedural justice dimension, there is a significant difference between teachers, whose schools have populations of " $0-500$ " and "1001-1500". There isn't a significant difference in interactional justice dimension in terms of school population variable. It can be seen that teachers' perceptions of organizational justice get more negative as the populations at their schools get higher. In terms of class population variable, there are significant differences in teachers' perceptions of organizational justice between teachers, whose classes have populations of " $0-30$ " and " $31-40$ " and between " $0-30$ " and " 41 or higher". In terms of class population variable, teachers have similar perceptions in procedural and interactional justice dimensions. Accordingly, teachers, who have more students in their classes, believe their acquisitions, such as duties, wage and awards are inadequate. Teachers' perceptions of organizational justice also 
vary by the social and sportive activities at schools variable. Accordingly, there are significant differences in distributive, procedural and interactional justice dimensions, between teachers, whose schools have "very adequate" and "medium level" and "inadequate" levels of activities, and between "medium level" and "inadequate" levels. Perceptions of teachers, whose schools have very adequate levels of social and sportive activities, are more positive than the teachers, whose schools have inadequate level of activities.

The related literature doesn't include any previous researches, which have studied the relationships between justice and violence perception variables. Yet, there are some researches, which have studied the variables of the present research separately. Başar and Sığrı (2015) studied the effects of teachers' perceptions of organizational justice on their leaving their jobs, and found that the perception of organizational justice had a significant effect on maintaining the job. The violence at schools, and managers' attitudes towards violence are also effective in teachers' maintaining their jobs. Demir (2015) studied the effects of organizational justice and perceived organizational support on organizational citizenship perception, and reported that teachers, who experience fair practices and don't experience problems at their schools exhibit more citizenship behaviours. In this context, we can claim that teachers, who don't encounter violence at schools, and believe that necessary measures are taken with fair practices, exhibit more citizenship behaviours. Polat and Kazak (2014) studied the relationship between school managers' favouring attitudes and behaviours and teachers' perceptions of organizational justice, found that favouring behaviours of managers result in decrease in teachers' perceptions of justice. Accordingly, we can claim that managers' reactions to violent incidents and their fair behaviours in this subject can cause differences in teachers' perspectives of justice. Similarly, Tziner and Sharoni (2014) reported in their research that work related stress can result in decrease in organizational justice perceptions. Another research conducted by Elovainio, Linna, Virtanen, Oksanen, Kivimäki, Pentti and Vahtera (2013) found that low organizational justice perception and negative incidents at work organizations can result in psychological health problems among employees in the long term. From this perspective, we can suggest that, constant violence incidents at schools and the managerial approaches towards violence incidents, especially the different and negative approaches can damage teachers psychologically.

According to the remarks of the participants of the present research on the reasons of violence, 14 items in the scale on violence are within "most of the time" range. On the other hand, 8 items are within "rarely" range. According to teachers' remarks, most of the reasons of violence are family related or about students themselves. There is a weak and negative correlation between teachers' perceptions of organizational justice and reasons of violence. Accordingly, as teachers' perceptions of justice are higher, their perceptions on the reasons of violence are lower. However, the correlation between teachers' perceptions of organizational justice and reasons of violence is weak. Additionally, teachers don't believe that the injustice they encounter at schools from their organizational justice perspective is the reason of violence at schools.

These findings of the present research are in agreement with the findings of similar researches in the literature. Peker (2015) reported in their research on violence at schools that security at schools is a sensitive issue that requires some measures taken by all parties at schools. This study conducted on psychological counsellors serving at schools aimed at investigating counsellors' remarks on school security and their roles in this issue. According to their findings, the factors affecting school security are physical and social environments of schools, teachers' and schools managers' attitudes, and the security systems of schools. Additionally, the research findings show that psychological counsellors have the necessary awareness and professional competence perceptions on their legal liabilities in security. Kankadai and King (2002) aimed at presenting pre-service teachers' remarks on violence at schools and tried to define the case for teachers before they start their service. In accordance with their findings, they emphasized the importance of pre-service trainings in preventing violence at schools and raising awareness on violence among teachers. Mooij (2011) stressed the importance of the perception of violence at school not only in terms of teachers, but also all parties at schools. This research included remarks of students, teachers and parents, and according to the findings teachers believed physical conditions and achievement at schools affected the phenomenon of violence at schools. Guetzloe (2000) reported that teachers could have awareness on potential/existing violence incidents at schools only with trainings on the issue. According to the researcher, teachers should have trainings on conflict solution, verbal attacks and anger management, and this should be guaranteed through legal regulations.

Yavuzer, Gündoğdu and Dikici (2009) studied the types and frequencies of the violence incidents that teachers serving at primary and high schools in a city of Turkey encounter. According to their findings, teachers defined violence as "a behaviour damaging verbally or physically" and believed that the reasons of violence were mainly family related. Lines (2007) stated that the most important factor that prevented education at schools was fights and violence incidents resulting from fights. Lines (2007) also stressed out the importance of knowledge and awareness of teachers on violence, and support programs were the solution to anger management, violence management and violence incidents among students. Cremin and Guilherme (2015) claimed that violence at schools is the most important issue that should be dealt not only at national but also at universal level. 
In accordance with the findings of the present and similar researches, the following suggestions can be developed. First of all, a significant result of the study is that intreractional justice perception differ in ages. Teachers who are at the neginnşig years of their professional lives perceive ineratctional justice in a lower level when compared to the older teachers. It can be concluded that teachers with low experiences perceive the attitudes without justice more, which shows that teachers who are at the beginning of the teaching profession have more sensitiveness for justice than the experienced teachers. For this reason, legal, administrative and organizatrional regulations should be determined and applied in order to main the sensitiveness of these unexperinced teachers for justice. Legally, in-service trainining activities should be reconsidered in frame of systems approach so as to increase the perceptions for organizational justice. That can be performed by providing equal opportunities for in-service training activities. As another dimension, according to the results of the study, as the number of the students and teachers increase, teachers' perceptions of justice decrease. This result shows that the number of students and teachers affecting the organizational justice in a negative way should be in contemporary norms. In crowded classrooms and schools, teachers' perceptions of justice show tendency to go negative and this situation also affect the success of education and performance negatively. Lastly, study resulst show that positive perceptions for organizational justice of teachers influence their perceptions for the results of the violence in a more positive way. So, one way of decreasing the violence in school can be increasing the perception of organizational justice. That can be ensured through the laws accenting justice and equality and equal administrative regulations.

\section{References}

Açıkgöz, A. (2009). Okul yöneticilerinin çatışma yönetim stilleri ile öğretmenlerin örgütsel adalet algısı arasındaki ilişki[The Relationship Between Administartors' Ways of Conflict Managemetn and Teachers' Perceptions of Justice]. Yayınlanmış yüksek lisans tezi[Unpublished Master Dissertation], Abant İzzet Baysal Üniversitesi, Bolu.

Adams, J. S. (1965). Inequity in social exchange. In L. Berkowitz (Ed.), Advances in experimental social psychology (Vol. 2) (pp. 267-299). New York: Academic Press. http://dx.doi.org/10.1016/s0065-2601(08)60108-2

Akyol, B., \& Akçay, C. (2013). Scale of Organizational Justice in Management Processes: A Validity and Reliability Study. The Journal of Academic Social Science Studies, 6(5), 147-164.

Ambrose, M. (2002). Contemporary Justice Research: A New Look At Familiar Question Organizational Behavior and Human Decision Processes, 89, 803- 812. http://dx.doi.org/10.1016/S0749-5978(02)00030-4

Başar, U., \& Sığrı, U. (2015). Effects of teachers' organizational justice perceptions on intention to quit: Mediation role of organizational identification. Educational Sciences: Theory \& Practice, 15(1), 45-59. http://dx.doi.org/10.12738/estp.2015.1.2326

Çınar, F. (2002). Örgütsel Adalet Kavramı ve Örgüt Yapısının Çalısanların Adalet Algılamları Üzerindeki Etkisi[The Concept of Organizational Justice and The Effect of Organizational Structure on Employees' Justice Perceptions]. İşletmelerde Çagdas Yaklasımlar, Editör: Sabuncuoglu Z., İ.İ.B.F. İşletme Bölümü, 31 - 43, Ezgi Kitapevi Yayınları, Bursa.

Cremin, H., \& Guilherme, A. (2015). Violence in Schools: Perspectives (and hope) from Galtung and Buber, Educational Philosophy and Theory.

Demir, K. (2015). The effect of organizational justice and perceived organizational support on organizational citizenship behaviors: The mediating role of organizational identification. Eurasian Journal of Educational Research, 60, 131-148. http://dx.doi.org/10.14689/ejer.2015.60.8

Elovainio, M., Linna, A., Virtanen, M., Oksanen, T., Kivimäki, M., Pentti, J., \& Vahtera, J. (2013). Perceived organizational justice as a predictor of long-term sickness absence due to diagnosed mental disorders: Results from the prospective longitudinal Finnish Public Sector Study. Social Science \& Medicine, 91, 39-47. http://dx.doi.org/10.1016/j.socscimed.2013.05.008

Greenberg, J. (1987). A Taxonomy of Organizational Justice Theories. Academy of Management Review, 16(2), 9-22.

Greenberg, J. (1990). Organizational Justice: Yesterday, Today and Tomorrow. Journal of Management, 16(2), 399-432. http://dx.doi.org/10.1177/014920639001600208

Guetzloe, E. (2000). Teacher preparation in the age of violence: What do educators need to know? The Teacher Educator, 35(3), 19-27. http://dx.doi.org/10.1080/08878730009555231

Gürpınar, G. (2006). Örgütsel Adalet, örgütsel bağl1lık, lider üye mübadele ilişkisi ve ayrılma niyeti arasındaki ilişkiler üzerine ampirik bir çalışma[An Empirical study of relationships among organizational justice, organizational commitment, leader-member exchange,and turnover intention], Yüksek Lisans Tezi[Master Disseration]. İstanbul: Yeditepe Üniversitesi Sosyal Bilimler Enstitüsü, İşletme Anabilim Dalı. 
Homans, G. C. (1961). Social behavior: Its elementary forms. New York: Harcourt, Brace, and World.

İçerli, L. (2010). Örgütsel adalet: Kuramsal bir yaklaşım[Organizational Justice: A conceptual Approach]. Girişimcilik Ve Kalkınma Dergisi, 5. Aksaray Üniversitesi İ̈BF, Aksaray.

Kandakai, T. L., \& King, K. A. (2002) Preservice Teachers' Beliefs regarding School Violence Prevention Training, American Journal of Health Education, 33(6), 350-356. http://dx.doi.org/10.1080/19325037.2002.10604759

Karasar, N. (2013). Bilimsel araştırma yöntemi[Scientific Research Method], (23. Baskı). Ankara: Nobel Yayınları.

Karataş, H. (2011). İlköğretim Okullarında Zorbalığa Yönelik Geliştirilen Programın Etkisinin İncelenmesi[The Research on The Effect of Program Developed for Bullying in Primary Schools], Doktora Tezi[Doctoral Dissertation], Dokuz Eylül Üniversitesi Sağlık Bilimleri Enstitüsü, İzmir.

Laçinoğlu, Z. (2010). İlköğretim okulu öğretmenlerinin örgütsel adalet algıları ile bazı örgütsel davranışları arasındaki ilişki[Relation between organizational justice perceptions and some organizational outputs of primary school teachers]. Yayınlanmış Yüksek Lisans Tezi[Unpublished Master Dissertation], Sakarya Üniversitesi, Sakarya.

Leventhal, G. S. (1980). What should be done with equity theory? InK. J. Gergen, M. S. Greenberg, \& R. H. Willis (Eds.), Socialexchange: Advances in theory and research. New York: Plenum. http://dx.doi.org/10.1007/978-1-4613-3087-5_2

Lines, D. (2007) Violence in School: What Can We Do? Pastoral Care in Education, 25(2), 14-21. http://dx.doi.org/10.1111/j.1468-0122.2007.00403.x

Mahiroğlu, A., \& Buluç, B. (2003). Ortaöğretim kurumlarında fiziksel ceza uygulamaları[Physical Punishment in Secondary Schools], Türk Eğitim Bilimleri Dergisi, Gazi Üniversitesi Yayınları, 1(1), 81-95.

MEB. (2008). Öğrencilerin Şiddet Algısı[Violence Perceptions of Students. Millî Eğitim Bakanlığı Eğitimi Araştırma ve Geliştirme Dairesi Başkanlığı[Ministry of National Education Directorate of Research and Development], Ankara.

Memduhoğlu, H. B., \& Taştan, M. (2007). Okul ve öğrenci güvenliği: Kavramsal bir çözümleme[School and Student Security: A Conceptual Analysis]. Çukurova Üniversitesi Eğitim Bilimleri Dergisi, 34(3), 69-83.

Mooij, T. (2011). Secondary school teachers' personal and school characteristics, experience of violence and perceived violence motives, Teachers and Teaching, 17(2), 227-253. http://dx.doi.org/10.1080/13540602.2011.539803

Niehoff, B. P., \& Moorman, W. V. (1993). Justice as a mediator of the relationship between methods of monitoring and organizational citizenship behavior. Academy of Management Journal, 36(3), 209-776. http://dx.doi.org/10.2307/256591

Özdevecioğlu, M. (2003). Algılanan örgütsel adaletin bireylerarası saldırgan davranışlar üzerindeki etkilerinin belirlenmesine yönelik bir araştırma[A Research on The Effect of Perceived Organizational Justice on Aggressive Behavior Aming People]. Erciyes Üniversitesi İktisadi ve İdari Bilimler Fakültesi Dergisi, 21, 77-96.

Parladır, S. (2009). Okullarda şiddetin kaynaklarına ilişkin öğretmen, yönetici ve öğrenci görüşleri[The opinions of teachers, administrators and students about the sources of violence at schools]. Yayınlanmış Yüksek Lisans Tezi[Unpublished Master Dissertation], Akdeniz Üniversitesi, Antalya.

Peker, A. (2015). The Perceptions of the Psychological Counselors about Their Roles and Responsibilities Related to School Security. Journal of Education and Training Studies, 3(6), 20-28. http://dx.doi.org/10.11114/jets.v3i6.1043

Polat, S. (2007). Ortaöğretim öğretmenlerinin örgütsel adalet algıları, örgütsel güven düzeyleri ile örgütsel vatandaşlık davranışları arasındaki ilişki[Relation between organizational justice perceptions, organizational trust levels and organzational citizenship behaviors of secondary education teachers]. Yayınlanmış doktora tezi[Unpublished Doctoral Dissertation], Kocaeli Üniversitesi, Kocaeli.

Polat, S., \& Kazak, E. (2014). The correlation between school principals' favoritist behaviors and attitudes and teachers' perception of organizational justice. Educational Administration: Theory and Practice, 20(1), 71-92.

Selekler, Z. O. (2007). Öğretmenlerde örgütsel adalet ve psikolojik sözleşme ihlal algısı[eachers' organizational justice and psychological contract violation perceptions]. Yayınlanmış Yüksek Lisans Tezi[Unpublishde Master Dissertation], Kocaeli Üniversitesi, Kocaeli.

TDK (2013). Güncel Türkçe Sözlük. Türk Dil Kurumu[Comtemporary Turkish Dictionary. Turkish Language Institution]. Erişim tarihi, 24 Mayıs 2013. http://www.tdk.gov.tr.

Tutar, H. (2004). İş Yerinde Psikolojik Şiddet Sarmalı: Nedenleri ve Sonuçları[Psyhological Violence in Workplace: Causes and Results], Yönetim Bilimleri Dergisi, 92-104. 
Tziner, A., \& Sharoni, G. (2014). Organizational citizenship behavior, organizational justice, job stress, and workfamily conflict: Examination of their interrelationships with respondents from a non-Western culture. Journal of Work and Organizational Psychology, 30, 35-42. http://dx.doi.org/10.5093/tr2014a5

Ünsal, A. (1996). Genişletilmiş bir şiddet tipolojisi[A Widened Violence Typology]. Cogito, 6-7.

Wasti, S. A. (2001). Örgütsel Adalet Kavramı ve Tercüme Bir Ölçeğin Türkçe'de Güvenirlik ve Geçerlik Analizi[The Concept of Organizational Justice and The Analysis of Reliability and Validity Analysis of A Translated Scale], Yönetim Araştırmaları Dergisi, 1, 33-50.

Yavuzer, Y., Gundogdu, R., \& Dikici, A. (2008). Teachers' Perceptions about School Violence in One Turkish City, Journal of School Violence, 8(1), 29-41. http://dx.doi.org/10.1080/15388220802067797 